\title{
PENINGKATAN KEMAMPUAN GURU DALAM PENERAPAN MODEL PEMBELAJARAN SENTRA MELALUI SUPERVISI AKADEMIK
}

\author{
Wiwin Yuli Astutik \\ Dinas Pendidikan Kota Mojokerto , Jl Benteng Pancasila 244 Mojokerto \\ E-mail: wiwinyuliastutik@gmail.com
}

\begin{abstract}
Improving Teachers' Abilities to Employ the Circle Centered Learning Model through Academic Supervision Method. The circle centered learning is the model that be can be used by many kindergartens in Indonesia. The ability of teachers in implement the model is various in quality. It is because the understanding of teachers about the model is different. In order to solve the problem, the teacher need a supervision. This research aimed to improve teachers' ability to employ the circle centered learning model through the academic supervision method. The research used action research design. The research was conducted in TK Koperasi Batik, Mojokerto. The result showed that academic supervision method could improved teachers' ability to employ the circle centered learning model, and the learning process could be carried out properly.
\end{abstract}

Keywords: implementation, circle-centered learning, academic supervision

\begin{abstract}
Abstrak: Peningkatan Kemampuan Guru dalam Penerapan Model Pembelajaran Berpusat pada Sentra melalui Method Supervisi Akademik. Pembelajaran berpusat pada sentra merupakan model pembelajaran yang banyak diterapkan pada TK di Indonesia. Penerapan guru dalam menggunakan model tersebut beraneka ragam kualitasnya. Hal tersebut dikarenakan setiap guru memiliki pemahaman yang berbeda-beda terhadapmodel tersebut. Untuk dapat memecahkan masalah tersebut perlu dilakukan supervisi kepada guru. Penelitian ini bertujuan untuk meningkatkan kemampuan guru dalam penerapan model pembelajaran berpusat pada sentra melalui kegiatan supervisi akademik. Penelitian dilakukan dengan rancangan penelitian tindakan. Penelitian ini dilaksanakan di TK Koperasi Batik, Mojokerto. Hasil penelitian menunjukkan bahwa kegiatan supervisi akademik dapat meningkatan kemampuan guru TK dalam penerapan model pembelajaran berpusat pada sentra, dan proses pembelajarannya dapat berjalan lebih baik.
\end{abstract}

Kata kunci: kemampuan guru, pembelajaran berpusat pada sentra, supervisi akademik

Pada Undang-Undang Republik Indonesia Nomor 20 Tahun 2003 Tentang Sistem Pendidikan Nasional Pasal 1 ayat 14 disebutkan bahwa pendidikan anak usia dini (PAUD) adalah suatu upaya pembinaan yang ditujukan kepada anak sejak lahir sampai usia enam tahun yang dilakukan melalui pemberian rangsangan pendidikan untuk membantu pertumbuhan dan perkembangan jasmani dan rohani agar anak memiliki kesiapan dalam memasuki pendidikan lebih lanjut. PAUD merupakan pendidikan utama bagi tumbuh kembangnya manusia. PAUD merupakan peletak dasar pertumbuhan fisik, sosioemosional, bahasa, dan komunikasi sesuai dengan keunikan perkembangan anak usia dini.

Sejumlah ahli mengatakan bahwa pendidikan keluarga berperan penting bagi tumbuh kembang anak. Pendidikan dapat terjadi karena panca indera 
dan pengalaman. Potensi yang dimiliki anak dapat dikembangkan melalui optimalisasi fungsi panca indera dan pengalaman anak. Lembaga penyelenggara pendidikan bagi anak usia dini merupakan salah satu satuan pendidikan yang dibangun untuk memberikan rangsangan kepada anak usia dini agar seluruh potensi yang dimiliki dapat tumbuh kembang secara optimal. Seluruh sajian lingkungan fisik dan non fisik yang digelar dan disuguhkan kepada anak di lembaga PAUD merupakan satu kesatuan utuh dan merupakan satu sistem yang diorientasikan untuk mengembangkan seluruh potensi yang dimiliki anak.

Kurikulum yang diterapkan, metode pembelajaran yang dipilih dan diterapkan dalam pembelajaran, performasi dan kinerja guru pengajar, dan segala hal yang berkaitan dengan kegiatan pembelajaran, harus seirama, karena halhal tersebut sebagai bagian dari "orkestra" yang diperuntukkan kepada anak agar dapat bertumbuhkembang dengan baik dan optimal. Apabila terjadi ketidakselarasan pada salah satu komponen atau subkomponen, maka dapat mengganggu berjalannya sistem yang dikembangkan di lembaga PAUD, dan hal tersebut dapat mempengaruhi proses tumbuh kembang anak. Oleh karena itu, penyelenggaraan pendidikan bagi anak usia dini sangat penting bagi proses perkembangan anak di masa pertumbuhan.

Pada saat ini, pembicaraan di kalangan pendidik PAUD tidak lepas dari metode pembelajaran BCCT (Beyond Centers and Circle Time) atau Pendekatan Sentra dan Lingkaran. Metode BCCT adalah suatu metode atau pendekatan dalam penyelenggaraan pendidikan anak usia dini yang bertujuan untuk merangsang seluruh aspek kecerdasan anak (kecerdasan jamak) melalui kegiatan bermain yang terarah. Adapun yang dimaksud dengan center (sentra) adalah zona atau area main anak yang dilengkapi seperangkat alat permainan yang berfungsi sebagai pijakan lingkungan. Pijakan lingkungan yang diperlukan untuk mendukung perkembangan anak terdiri dari tiga jenis permainan, yaitu main sensorimotor (fungsional), main peran, dan main pembangunan. Circle Times adalah saat pendidik duduk bersama anak dengan posisi melingkar untuk memberikan pijakan kepada anak, yang dilakukan sebelum dan setelah main. BCCT dianggap sebagai metode paling ideal untuk diterapkan dalam
PAUD. Meskipun tidak memerlukan peralatan yang banyak, melalui BCCT, kecerdasan anak tetap dapat dioptimalkan. BCCT diyakini mampu merangsang seluruh aspek kecerdasan anak (multiple inteligent) melalui bermain yang terarah. Pola pembelajarannya mampu merangsang anak untuk dapat aktif, kreatif, dan terus berpikir dengan menggali pengalamannya sendiri.

Pembelajaran berbasis sentra adalah model pembelajaran yang dilakukan di dalam "lingkaran" dan sentra bermain. Lingkaran merujuk pada saat guru duduk bersama peserta didik dengan posisi melingkar untuk memberi pijakan kepada anak yang dilakukan sebelum dan setelah bermain. Sentra bermain adalah arena bermain anak yang dilengkapi dengan seperangkat alat bermain. Alat bermain berfungsi sebagai pijakan lingkungan yang diperlukan untuk mengembangkan potensi dasar anak dalam berbagai aspek perkembangan secara seimbang. Setiap sentra diorientasikan untuk mendukung perkembangan anak dalam tiga hal, yaitu sensori motor, bermain peran, dan bermain konstruktif (Mulyasa, 2012). Sentra bermain terdiri atas bahan alam atau sains, balok, seni, bermain peran, persiapan, agama, dan musik. Pada setiap aspek tersebut memiliki bahan dan isi yang berbeda.

Bermain sensor motor bertujuan untuk menangkap rangsangan melalui pengindraan dan menghasilkan gerakan sebagai reaksi. Melalui penginderaan, anak berhubungan dengan lingkungan fisik di sekitarnya. Bermain peran berorientasi pada dua hal, yaitu makro dan mikro. Bermain makro merupakan kegiatan bermain sebenarnya, sedangkan bermain mikro adalah bermain simbolik, fantasi imajinatif. Melalui benda tertentu, anak dibantu untuk dapat menghadirkan konsep yang dimiliki. Bermain konstruktif berorientasi pada pengembangan kemampuan anak untuk mewujudkan pikiran, ide atau gagasan menjadi karya nyata. Bermain konstruktif terbagi dalam dua kategori, yaitu bermain konstruktif sifat cair dan bermain konstruktif tersetruktur (Mulyasa, 2012).

TK Koperasi Batik merupakan salah satu lembaga pendidikan yang menyelenggarakan layanan pendidikan bagi anak usia dini di kota Mojokerto. TK ini telah diterapkan model pembelajaran sentra sejak tahun pelajaran 2014- 
2015. Ada 4 sentra yang diterapkan. Berdasarkan hasil penelitian pendahuluan, diketahui bahwa implementasi model pembelajaran sentra belum optimal. Cara guru dalam membimbing anak pada saat circle time masih seperti sistem kelas (klasikal), belum menunjukkan keceriaan anak. Anak masih terlihat kaku dan kurang merasa senang dengan pembelajaran. Proses pembelajaran pada setiap pijakan masih belum mewujudkan pembelajaran sentra. Pengarahan anak untuk belajar secara sentra masih belum terlihat, karena guru masih mendominasi kegiatan, sehingga anak cenderung hanya meniru kegiatan guru, anak belum sepenuhnya diberi kesempatan untuk bereksplorasi. Berdasarkan temuan awal tersebut, maka perlu dilakukan pembinaan dan pendampingan kepada guru-guru berkaitan dengan apa dan bagaimana model pembelajaran sentra seharusnya dilakukan.

\section{METODE}

Pendekatan kualitatif dipilih untuk mendapatkan gambaran-gambaran mengenai tingkah laku subjek penelitian selama proses pembelajaran dengan pemberian suatu tindakan. Di samping itu pendekatan ini dipilih karena penelitian ini memenuhi kriteria penelitian kualitatif seperti (1) pengumpulan data dilakukan dalam kondisi yang wajar atau alamiah (natural setting). Dalam hal ini, peneliti menyelidiki dan memaparkan data secara alami seperti apa adanya di lapangan, (2) peneliti merupakan instrumen utama dalam mengumpulkan dan menginterpretasikan data, hal ini dilakukan karena jika memanfaatkan alat yang bukan manusia dan mempersiapkannya terlebih dahulu sebagai yang lazim digunakan dalam penelitian klasik, maka sangat tidak mungkin untuk mengadakan penyesuaian terhadap kenyataan yang ada di lapangan, (3) bersifat deskriptif, karena data yang terkumpul sebagaian besar hanya berupa kata-kata atau kalimat, sedangkan data yang berupa angka hanya data hasil belajar siswa yang pada akhirnya angka-angka tersebut akan diolah dan dianalisis sehingga dapat diungkapkan dengan menggunakan kata-kata atau kalimat, dan (4) lebih mementingkan proses daripada hasil, karena hubungan bagian-bagian yang diteliti lebih jelas apabila diamati dalam proses (Moleong, 2002).

Sedangkan jenis penelitian yang digunakan dalam penelitian ini adalah Penelitian Tindakan
Kelas (PTK) atau class action research. Esensi dari penelitian tindakan terletak pada adanya tindakan dalam situasi alami untuk menyelesaikan permasalahan-permasalahan praktis pengajaran. PTK berangkat dari persoalan-persoalan praktis yang dihadapi guru di kelas (Susilo, 2004). Menurut Arikunto (2010) penelitian tindakan kelas dilakukan melalui 4 tahapan berikut, yaitu yaitu: (1) perencanaan; (2) pelaksanaan; (3) pengamatan; dan (4) refleksi. Penelitian dilakukan di TK Koperasi Batik, Kota Mojokerto, dan dengan guruguru di TK tersebut sebagai subyek penelitian. Teknik pengumpulan data menggunakan observasi, wawancara dan studi dokumentasi. Data yang terkumpul dianalisis dengan menggunakan teknik analisis kualitatif. Penelitian ini dilakukan di TK Koperasi Batik, Mojokerto. Penelitian tindakan ini dilakukan melalui dua siklus.

\section{HASIL DAN PEMBAHASAN}

\section{Hasil}

\section{Siklus I}

Pada tahap perencanaan, peneliti melakukan penyusunan jadwal penelitian bersama kolaborator yaitu kepala sekolah. Kemudian menyiapkan instrumen penilaian kemampuan guru dalam kegiatan proses belajar mengajar sesuai dengan tugas utama seorang guru yaitu, mendidik, mengajar, membimbing, mengarahkan, melatih, menilai dan mengevaluasi peserta didik. Penelitian dengan tujuan perbaikan kegiatan pembelajaran dengan model pembelajaran sentra dilakukan melalui supervisi akademik.

Pada tahap pelaksanaan tindakan, kepala sekolah melakukan kunjungan kelas dengan tujuan untuk mengetahui secara langsung pelaksanaan model pembelajaarn sentra. Pengawas melakukan observasi dan supervisi kepada para guru berkaitan dengan (a) penyusunan rencana pembelajaran model pembelajaran sentra: program semester, RPPM, dan RPPH; (b) pelaksanaan pembelajaran model pembelajaran sentra; dan (c) pelaksanaan penilaian kegiatan.

Pada tahap pengamatan, peneliti melakukan observasi dan sekaligus memberikan supervisi akademik berkaitan dengan rencana pembelajaran dan cara guru menerapkan rencana tersebut pada kegiatan pembelajaran dengan model 
pembelajaran sentra. Pada tahap refleksi, ditemukan beberapa kekuatan dan kelemahan dalam pelaksanaan pembelajaran dengan model pembelajaran sentra. Adapun kekuatan yang ditemui pada saat pelaksanaan penelitian adalah sebagai berikut: (1) perencanan pembelajaran telah tersusun degan baik, rapi dan tertib; (2) guruguru memiliki dedikasi dan semangat yang tinggi dalam mengajar, (3) adanya kepala sekolah yang ikut mengajar; 4) meskipun jumlah guru minim, namun berani menggunakan model pembelajaran sentra; 5) meskipun telah menerapkan Kurikulum 2013, guru tetap menerapkan model pembelajaran sentra; dan 6) adanya ruang yang cukup untuk pembelajaran sehingga memudahkan anak-anak untuk bergerak. Sedangan kelemahan yang ditemui pada saat pelaksanaan penelitian adalah: (1) pembelajaran masih berpusat pada guru, karena guru cemderung menguasai kegiatan, belum memberikan kesempatan kepada anak secara penuh; 2) minimnya alat permainan di dalam kelas sehingga densitas yang sesuai dengan tema belum dapat terpenuhi; 3) penilaian yang dilakukan guru belum sepenuhnya menyeluruh karena penilaian terprogram yang telah disusun belum djalankan sepenuhnya.

Hasil pelaksanaan tindakan melalui supervisi akademik yang dilakukan oleh pengawas dan dengan melihat kekuatan dan kelemahan guru tersebut akan dijadikan pijakan untuk memperbaiki tindakan pelaksanaan di siklus II. Pada siklus I, indikator keberhasilan mencapai 75\%. Hal ini dibuktikan dengan lembar observasi yang digunakan oleh peneliti pada saat pelaksanaan tindakan. Hasil observasi tersebut menunjukkan bahwa kemampuan yang dicapai oleh guru TK Koperasi Batik telah menyeluruh, namun terdapat satu guru baru yang masih perlu panduan dan bimbingan. Sehingga walaupun tingkat keberhasilannya telah mencapai $75 \%$, penelitian di siklus II tetap akan dilanjutkan untuk pemantapan hasil siklus I.

\section{Siklus II}

Pada tahap Perencanaan, rencana kegiatan awal pada siklus II sama seperti halnya pada siklus I. Peneliti sebagai pengawas mengadakan supervisi kembali, namun langsung melihat proses pembelajaran yang sedang berlangsung
Hal tersebut dilakukan untuk mengetahui secara langsung perbaikan yang dilakukan guru dalam mengajar dengan model pembelajaran sentra.

Pada tahap pelaksanaan, pengawas mengadakan pendampingan dengan tehnik supervisi individual terhadap masing-masing guru yang dirasa masih memerlukan bantuan. Guru yang masih baru akan diberikan pendampingan yang lebih sebagai proses induksi guru baru. Adapun kegiatan yang dilakukan pengawas adalah sebagai berikut: (1) pertemuan pertama, pendampingan pembelajaran, seperti halnya pada siklus I, kegiatan awal adalah mendiskusikan prosedur penyusunan perencanaan pembelajaran dengan melihat kekuatan serta kelemahan yang dihadapi oleh masing-masing guru yang ditemui pada pelaksanaan tindakan di siklus I. Kemudian diskusi kelompok, untuk memecahkan masalah yang masih menjadi kendala yang dihadapi pada saat pelaksanaan pembelajaran dengan model pembelajaran sentra. Terutama kelemahan guru dalam proses pembelajaran didiskusikan bersama-sama untuk ditemukan solusi yang tepat. Pengawas memberikan contoh cara mengajar yang benar yang berpusat pada anak, tidak terlihat kaku, serta mengalir secara alami namun tetap memperhatian peraturan disetiap pijakan lingkungan sehingga proses pembejaran dengan model pembelajaran sentra dapat terlihat jelas; 2) pertemuan kedua, supervisi akademik, melihat secara langsung pelaksanaan pembelajaran dan mengadakan pengamatan dengan menggunakan lembar observasi yang telah disusun. Dalam hal ini pengawas telah melihat kemajuan yang baik dibandingkan dengan pelaksanaan di siklus I. Sebagai contoh, pada saat peneliti berada di sentra alam, peneliti melihat pembelajaran dilaksanakan diluar kelas karena sesuai dengan tema yang digunakan dan memberikan kebebasan anak untuk mengenal alam lebih dekat. Disini anak dapat bermain dengan bebas, namun tetap terarah sesuai pijakan yang di buat oleh guru. Kemudian saat peneliti melihat di sentra seni, kegiatan juga telah baik. Anak-anak belajar membuat kreasi sendiri dengan alat dan media yang disediakan oleh guru, disni guru hanya mengarahkan kegiatan sesuai tema, selebihnya anak membuat kreasi sendiri sesuai dengan kreativitasnya. Kemudian yang paling menarik adalah ketika peneliti berada 
di sentra main peran di sana ada setting kegiatan bermain dokter-dokteran, guru telah menata tempat sesuai dengan ruangan dokter lengkap dengan kursi tunggu, tempat tidur anak, meja dokter dan kursinya. Diatas meja terdapat lembaran kertas dan pensil untuk menulis resep, stetoskop dan alat pengukur tensi darah. Selain itu juga disediakan baju dokter dan perawat, sehingga anak-anak merasa senang manjadi seorang dokter dan perawat. Dalam sentra peran ini, guru hanya menunjukkan peralatan yang akan digunaan untuk bermain, selebihnya anakanak bermain sendiri dengan temannya sesuai peran yang dimainkan. Begitu juga saat disentra agama, anak-anak diajak bermain sambil belajar praktik sholat lengkap dengan menggunakan peralatan sholat yang dipersiapkan oleh guru. Sebelum praktek sholat, guru mengajak anak-anak terlebih dahulu untuk berwudhu menggunakan kran air di depan kelas. Dari hasil pengamatan pada saat proses pembelajaran di masing-masing sentra, diketahui bahwa rata-rata guru telah memahami model pembelajaran sentra, anak-anak telah mendominasi kegiatan, sedangkan guru hanya sebagai fasilitator saja, anak belajar dengan aktif, kreatif serta menyenangkan.

Pada tahap pengamatan, dari hasil pelaksanaan pendampingan dan diskusi pada siklus II ini, dapat dijabarkan hal-hal sebagai berikut: (1) guru telah mulai memahami model pembelajaran sentra; (2) pembelajaran telah berpusat pada anak; (3) proses kegiatan pembelajaran telah berjalan sesuai dengan RPPH; (4) anak belajar sambil bermain dengan aktif, kreatif dan menyenangkan; (5) hasil kegiatan di pajang diatas papan flannel oleh masing-masing anak, sehingga anak merasa bangga dengan hasil karyanya sendiri; (6) dalam seni peran, anakanak sangat antusias sekali dalam bermain sambil belajar mengenal dunia kedokteran; dan (7) guru telah mampu mengadakan penilaian.

Pada tahap refleksi, dari hasil pengamatan yang dilakukan peneliti pada saat pendampingan dan supervisi akademik, dengan hasil yang telah dijabarkan diatas maka pada siklus II ini, penelitian telah diangap berhasil karena tujuan pembelajaran sentra telah berpusat pada anak. Kegiatan dilakukan sesuai dengan pijakan lingkungan, sebelum main, saat main dan setelah main, serta pembelajaran sesuai dengan perencaanaan yang di buat. Anak belajar sambil bermain dan guru memberikan kesempatan kepada anak untuk belajar lebih mandiri. Sehingga tidak perlu lagi dilakukan pelaksanaan siklus ke III. Dari hasil pelaksanaan kegiatan pada siklus II, indikator keberhasilan telah meningkat signifikan. Dari keempat sentra yang dibuka yaitu sentra agama, sentra seni, sentra bahan alam, dan sentra main peran, keempatnya telah menunjukkan model pembelajaran sentra yang sesungguhnya, sehingga dapat dipresentasikan. Dari hasil observasi, menunjukkan bahwa terdapat peningkatan sebesar $85 \%$, sehingga supervisi akademik yang dilakukan oleh pengawas telah mampu memperbaiki model pembelajaran sentra di TK Koperasi Batik.

\section{Pembahasan}

Secara umum, temuan penelitian menunjukkan bahwa penerapan metode supervisi akademik dapat meningkatkan pemahaman dan kemampuan guru dalam menerapkan model pembelajaran berbasis sentra, dan proses pembelajaran yang dijalankan dapat berjalan lebih baik sesuai dengan standar pembelajaran berbasis sentra. Temuan penelitian ini sejalan dengan hasil penelitian Iwantoro (2014), bahwa supervisi berpengaruh secara signifikan terhadap peningkatan kinerja guru dalam rangka mencapai tujuan pendidikan. Supervisi pendidikan berperan memberikan kemudahan dan membantu guru mengembangkan potensi secara optimal. Supervisi dapat meningkatkan kompetensi guru sehingga dapat mencapai efektifitas dan efisiensi program sekolah secara keseluruhan. Melalui supervisi, guru diberikan kesempatan untuk meningkatkan kinerja, dilatih untuk memecahkan berbagai permasalahan yang dihadapi. Hamalik (2006) menyebutkan bahwa supervisi merupakan segala usaha yang dilakukan supervisor dalam bentuk pemberian bantuan, bimbingan, pergerakan motivasi, nasihat, dan pengarahan yang bertujuan untuk meningkatkan kemampuan guru dalam proses belajar mengajar, yang pada gilirannya dapat meningkatkan hasil belajar siswa. Supervisi merupakan upaya pembinaan kepada personil sekolah, termasuk guru, agar kualitas pembelajarannya meningkat. Peningkatan kualitas pembelajaran, menurut Kurnia (2010) dapat meningkatkan prestasi belajar siswa. Artinya, kegiatan supervisi mempunyai konskuensi logis bahwa seorang guru harus siap disupervisi setiap 
saat. Jika guru dan kepala sekolah telah memahami fungsi dan peran supervisi, maka problem pendidikan akan mudah dipecahkan.

Monitoring dilakukan sebagai bagian dari tugas pengawas untuk melihat dan memotret secara langsung pembelajaran yang sedang berlangsung di TK Koperasi Batik Kota Mojokerto. berdasarkan hasil observasi awal ditemukan beberapa hal yang berkaitan dengan proses belajar mengajar, diantaranya adalah: (1) model pembelajaran yang diterapkan di TK Koperasi Batik menggunakan model pembelajaran sentra; (2) sarana dan parasarana untuk mendukung pembelajaran telah baik yaitu gedung dan lingkungan halaman yang luas; (3) namun untuk densitas sebagai pendukung kegiatan di sentra masih belum terpenuhi, media masih minim dan permainan di dalam juga masih minim dan banyak mainan yang telah lama dan kurang terawat; dan (4) proses pembelajaran sentra masih belum berpusat pada anak, sehingga kegiatan masih didominasi oleh guru, anak cenderung menirukan guru, anak belum bereksplorasi sendiri. Dari beberapa penemuan tersebut, maka peneliti bersama dengan kepala sekolah menyusun jadwal penelitian untuk mengadakan perbaikan model pembelajaran sentra.

Dari hasil penelitian tindakan yang dilakukan di TK Koperasi Batik Kota Mojokerto, diperoleh hasil sebagai berikut: (1) pada Siklus I ditemukan bahwa kemampuan guru dalam melaksanakan model pembelajaran sentra telah mencapai $75 \%$; (2) hasil penelitian Siklus II menunjukan kemampuan guru dalam melaksanakan pembelajaran sentra meningkat signifikan hingga $85 \%$. Dari hasil penelitian pada Siklus I dan II, maka penelitian ini telah dianggap berhasil, karena telah indikator keberhasilannya mencapai $85 \%$. Guru telah mampu melaksanakan model pembelajaran sentra dengan baik dan benar. Hal ini sesuai dengan tujuan pembelajaran sentra yang dikemukaan oleh Arriyani(2010), sentra dapat diartikan sebagai suatu wadah yang disiapkan guru bagi kegiatan bermain anak. Sehingga dapat disimpulkan bahwa supervisi akademik dapat meningkatkan kemampuan guru dalam melaksanakan model pembelajaran sentra di TK Koperasi Batik. Hal tersebut sesuai dengan pendapat Glickman, dalam Pamela (2007), dimana supervisi akademik adalah serangkaian kegiatan membantu guru mengembangkan kemampuannya mengelola proses pembelajaran. Sehingga penelitian yang dilakukan oleh peneliti sebagai pengawas telah dikatakan tuntas.

\section{KESIMPULAN DAN SARAN}

\section{Kesimpulan}

Berdasarkan proses dan hasil penelitian tindakan yang diperoleh dalam penelitian ini, dapat dikemukakan beberapa kesimpulan sebagai berikut: (1) model pembelajaran sentra yang dilaksanakan di TK Koperasi Batik telah berjalan dengan baik, mulai penyusunan perencanaan pembelajaran yang meliputi Program Semerter, RPPM, RPPH dan Penilaian, dan semua perencanaan telah terdokumentasi dengan baik dan rapi; (2) supervisi akademik dapat memperbaiki proses pembelajaran yang dilaksanakan di TK Koperasi Batik sesuai dengan perencanaan yang telah dibuat; (3) teknik supervisi akademik yang dilakukan oleh peneliti sebagai pengawas meliputi kegiatan kunjungan kelas (untuk monitoring pembelajaran), observasi kelas (untuk melihat dan memotret secara langsung proses pembelajaran), serta pertemuan individual (untuk mengadakan percakapan atau dialog tentang hambatan serta kesulitan maupun dalam memperoleh data-data untuk kelengkapan instrumen).

\section{Saran}

Berdasarkan hasil penelitian ini, maka dikemukakan saran-saran sebagai berikut: (1) mengingatsupervsisiakademikdapatmeningkatkan kemampuan guru dalam melaksanakan model pembelajaran sentra, maka hendaknya para pengawas TK lain juga menggunakan supervisi akademik untuk peningkatan pembelajaran yang lain; (2) untuk memperoleh hasil yang lebih baik, hendaknya dilakukan penelitian tindakan sekolah lanjutan, dengan sasaran yang lebih luas untuk memperoleh hasil yang lebih komprehensif; dan (3) untuk melaksanakan penelitian tindakan sekolah lanjutan, perlu dukungan kerja sama dengan pengawas lainnya untuk pemerataan kemampuan guru di TK Kota Mojokerto sehingga semua guru mampu melaksanakan proses pembelajaran dengan baik dan benar. 


\section{DAFTAR RUJUKAN}

Arikunto, S. 2010. Prosedur Penelitian Suatu Pendekatan Praktik. Jakarta: Rineka Cipta.

Arriyani. 2010. Sentra Main Peran. Jakarta: Pustaka Al-Falah.

Hamalik, O. 2006. Manajemen Pengembangan Kurikulum. Bandung: Remaja Rosdakarya.

Iwantoro. 2014. Kompetensi Supervisi Kepala Sekolah Meningkatkan Kinerja Guru Dalam Rangka Mencapai Tujuan Pendidikan. Jurnal Ilmu Tarbiyah "At-Tajdid” Vol 3 Nomor 2, Juli 2014.

Kurnia, I. 2010. Peningkatan Kinerja Guru Melalui Kegiatan Supervisi Kepala Sekolah. Jurnal Visi Ilmu Pendidikan.

Moleong, L. J. 2002. Metodologi Penelitian Kualitatif. Bandung: Remaja Rosdakarya.
Mulyasa, H. E. 2012. Manajemen PAUD. Bandung: Remaja Rosdakarya.

Pamela C. P. 2007. Ocean and the Sea Life, Beyond Centers and Circle Time Theme Series, Creative Center or Childhood Research and Training, Inc. (CCCRT).

Susilo, H. 2004. Pembelajaran Sains Secara Konstruktivis-Kontekstual untuk Menggalakkan Kemampuan Berpikir Siswa. Jurnal Pelatihan PBMP (Pemberdayaan Melalui Pertanyaan) Pada Pembelajaran Bagi Guru Sains Biologi. Malang: Lembaga Penelitian Universitas Negeri Malang.

Undang-Undang Republik Indonesia Nomor 20 Tahun 2003 Tentang Sistem Pendidikan Nasional. (Online), (http://www.sindikker. dikti.go.id), diakses 17 November 2016. 